\title{
Sukuk: Measuring the Role of Sukuk As an Economic Growth Enhancer in Turkey
}

\author{
Mohammed M. I. Alkhawaja \\ Social Sciences Institution Sakarya University, Sakarya, Turkey \\ Correspondence Author: Mohammed M. I. Alkhawaja, Social Sciences Institution Sakarya University, Sakarya, Turkey \\ Tr.alkhawaja@gmail.com
}

Received date: 10 January 2019, Accepted date: 25 February 2018, Online date: 28 February 2019

Copyright: (c) 2019 Mohammed M. I. Alkhawaja. This is an open-access article distributed under the terms of the Creative Commons Attribution License, which permits unrestricted use, distribution, and reproduction in any medium, provided the original author and source are credited.

\begin{abstract}
As a result of continuous development of Islamic finance, we find Sukuk (which is also referred to as Islamic Bonds) as the most developed profit-loss sharing-based investment tool which is characterized by its simplicity, flexibility, and diversity. The aim of this study is measuring the impact of both sovereign and private Sukuk on Turkish GDP during the period 2010-2017 through analyzing reports published by Turk Participation Banks Union (TPBU), In this study we briefly view Sukuk history, identify sukuk, differentiate between Sukuk and bonds, show the development of Turkish Sukuk market and finally measure the impact of Sukuk on Turkish GDP. The study concludes that, Sukuk issuance is not totally independent from country's economic situation as it has been severely affected by country's GDP drop in 2015, on the other hand government is the major player in Sukuk market in turkey, as the total sovereign Sukuk issuance in Turkey during the study period was about \$12.1 B while private Sukuk issued during the same period totaled $\$ 8.5$ B. The impact of Sukuk on GDP how was increasing gradually to reach $0.54 \%$ in 2017 .
\end{abstract}

Keywords: Sukuk, Bonds, GDP, Turkey, Economic growth

\section{INTRODUCTION}

\section{Brief History}

Sukuk debut was in Malaysia in 1990 when Shell MDS Sdn Bhd (non-Islamic corporation) issued first Islamic bond (Laldin, 2008, P.229), after that there was no active Sukuk issuance until 2001 when more players such as Bahrain Government, and Singapore started issuing Islamic bonds (Dusuki, 2009, P.9). Jobst 2008 in his study related to the period 2003-2007 he mentioned that have of the issued sukuk in terms of value originates from Asia countries such as Malaysia and Brunei while the second half originates from GCC countries (Saudi Arabia, Bahrain, and Qatar) and Pakistan. In the same study, Jobst says that although US Dollar has globally dominated Sukuk issuance there was an tendency for decreasing Dollar Sukuk issuance as a result to increasing demand for domestic currency issues and USD's decreasing value, so the percentage of Dollar issued has dropped from \%85 in 2002 to about $\% 50$ in 2007. Sukuk Market witnessed a rapid growth since 2001 when Sukuk totaled less than $\$ 500 \mathrm{M}$ and until 2007 when it exceeded \$60 Billion (Damak, Volland, 2008, P.2), but in 2008 under the impact of Global Financial and due to high financial uncertainty got downsized by about 50\% (Ulusoy, Ela, 2018, P.100).

\section{Definition}

The reason behind Sukuk lies in Islamic finance principles which mainly prohibits interest and recommends profit-loss sharing, if we look at the origins of the word Sukuk in the ancient ages we find that it is in Arabic language the plural case of the word Sakk which means a paper representing a financial load or obligation (Safari, 2013, P.81). Sukuk can be defined as an assetbacked paper representing periodic partial ownership of a business, as the Sukuk holders gain a margin of profit born by the subject business and receive the market value of the paper at the end of the period. While according to AAOIFI Sukuk are investment certificates with equal values (Kusasi, Et Al., 2015, P.100) According to Afshar, 2013 Sukuk holder has a proportional ownership of a specific asset or a group of assets, thus he gains a share of profit generated by the asset and gets exposed to the risks associated with this asset.

\section{Comparison between Sukuk and Bonds}


As Sukuk is considered the Islamic version of bonds, here we explain the differences between them as mentioned by AAOIFI Shariah Council president Usmany, 2007; Firstly, Bonds are interest-bearing debt documents and do not represent any ownership related to the asset or property while Sukuk represents the ownership of the asset. Secondly, bonds promise interest determined as a percentage of bonds issuance value while bonds promise payment based on the real profits generated by the asset by which Sukuk are backed. Third, in bonds principal is guaranteed so the bondholder is that he will take back his capital at the maturity date, related to Sukuk, however, at maturity date Sukuk holders receive their shares from the market value of the asset price.

\section{Advantages of Sukuk investment}

According to Usmani 2007, Sukuk is one the best tools for financing projects bigger than being funded by one party, and for banks it is a good way for managing liquidity so when they have excessive liquidity they can invest them through buying Sukuk and sell them in the secondary market when they are in need for liquidity, the same thing can be said related to investors as they can deploy their capital or liquidate their Sukuk when they need. For the economy as a whole, Sukuk enhances the distribution of wealth through investing in real projects that support the circulation of the wealth on a broader scale.

\section{Sukuk Basic Structure}

Basically the originator of Sukuk establish what is called Specific Purpose Vehicle (SPV) which is practicing as the agent of investors, SPV works as a subsidy for the originator collects funds from investors to finance the planed asset or project, during the agreed period SPV gives the generated profits to Sukuk holders and at maturity date originator buys the underlying asset from Sukuk holders (lackmann, 2015, P:1,2) (Ismail, 2010, P:3,4).

\section{Sukuk development and growth in Turkey}

First Sukuk issuance in Turkey was on 24.08.2010 under the name Lease Certificates, it was realized by Kuveyt Turk participation bank and amounted for $\$ 100$ Million based on principles identified by "Communiqué on the Principles Regarding Lease Certificates and Asset Lease Companies, serial III, numbered 43" which was published by Capital Markets Board (Sarıkatipoğlu, et al. 2015, P:4). According to the Capital Markets Board, Asset Leasing Company (ALC) practices the role of Specific Purpose Vehicle (SPV), thus investors rights get more secured (IFM Sukuk report 2018, P.178). As the above-mentioned communiqué allowed companies to issue only lease Sukuk, on 07.06.2013 "Communiqué on the Principles Regarding Lease Certificates and Asset Lease Companies, serial III, numbered 61.1" has been published, the new communiqué has allowed ALCs to issue lease certificates for other companies who are in need of fund, and added five more new types of Sukuk to be issued (Ela, 2015, P.158). While the regulations published in 2010 allowed private sector corporations in Turkey to issue Sukuk, there was a need for new regulation to open the door for issuing sovereign Sukuk, as a result on 29.06.2012 a new paragraph has been added to 749 numbered law, according to this update, undersecretaries of treasury has the ability to issue Sukuk for the local and international market, based on the mentioned regulations Turkish government issued Ijara Sukuk for the first time on 29.09 .2012 to the global market and amounted to \$1.5 Billion with 66-month maturity period (Ulusoy, Ela, 2015, P.159). Kuveyt Turk participation bank issued Sukuk for the second time on 30.10.2011, it amounted for $\$ 350$ Million with 5-year maturity period and semi-annual profit payment bases with 5.75\% fixed income rate (Aslan, 2012, P.101).

\section{Literature}

In a study conducted by Buyukakin, Onyilmaz in 2012, researcher have mentioned the role of Sukuk in employing the idle money owned by people who are sensitive toward Islamic Sharia principles for improving real economy, as it is a good way to strengthen the economy with low cost. Researched have the role of Sukuk in economic development, and mentioned the necessity of required regulations related to Sukuk issuance and taxation in Turkey.

In 2014, Ozeroglu has conducted an informative study about Sukuk and the value it might add to the country economy, according to the study as some aspects of Sukuk are still under discussion by Sharia scholars, the majority has stated Sukuk as Sharia-compliant financial instrument, on the other hand, Sukuk issuance will add an extra value to the economy, and in case of issuing TL currency Sukuk it will strengthen Borsa of Istanbul and support Turkish exports. The researcher has mentioned that sovereign Sukuk is a good method for financing projects that could not financed by tax incomes.

In another study conducted by Alpaslan and Kudun in 2016, researchers briefly viewed participation banks, introduced the first stages of Sukuk issuance in the world and explained Sukuk position in Turkey with a focus on legal regulations related to issuance laws and taxation. According to the study, Sukuk issuance in Turkey was late as the first regulation was in 2010 under the name lease certificates, on the other hand, the increased demand by investors from Asia and the Middle East supports Sukuk development. Researchers have mentioned that as lease certificated are based on real assets it is easier to gain investors trust. The study is highlighting the continuous governmental efforts to remove all barriers hindering Sukuk investment, these efforts can be exemplified by taxation advantages offered by the government to facilitate Sukuk investment, e.g., while tax deduction from interest gained annually by saving accounts is $12 \%, 10 \%$ is deducted from income gained by Sukuk. This study has introduced Sukuk issuance stages in Turkey without measuring performance or effect on Turkey economic growth.

Ulusoy and Ela in 2016 have conducted a study on Sukuk issuance in Turkey with a focus on Sovereign Sukuk and legal regulations, the provided detailed explanation of Sukuk types and characteristics, the researchers have mentioned that although Muslims represent $97 \%$ of the population in Turkey it has just prepared regulations needed for Sukuk issuance. On the other hand, although regulations for issuing five types of Sukuk taxation laws only include Ijara Sukuk, so that only Ijara Sovereign Sukuk are issued by the Turkish government, this situation necessitates making the required regulation for issuing different types of Sukuk as Ijarah carry some criticisms from Sharia scholars which states that Ijarah Sukuk is not free from Sharia-compliance risk. In 
general, the study has criticized Sukuk issuance related regulation in Turkey and shown in numbers the amounts of sovereign Sukuk issued in Turkey since 2012 until 2016.

\section{Data and Analysis}

The study employed data associated with both private and sovereign Sukuk issuance in Turkey in the period 2010-2017, according to data, fist Sukuk issuance in Turkey was in 2010 by private sector and totaled $\$ 100 \mathrm{M}$, while the first sovereign Sukuk issuance was in 2012 and totaled \$1.5 B. During the period of study, both private and sovereign Sukuk issuances fluctuated while it has dropped sharply in 2015 as the total GDP of the country declined in that year, in 2016 sovereign Sukuk issuance totaled about \$3B while private Sukuk issuance totaled about \$2B. In 2017, the last year of study, however, total Sukuk issuance was $\$ 4.63$ B. chart 1 shows both private and sovereign Sukuk issuance during the period of study while in Chart 2 the study exhibits to total Sukuk issuance in Turkey during the study period. It can be noticed that Turkish Sukuk issuance was increasing rapidly as it was the beginning of Turkish Sukuk Market and Turkey has succeeded attracting foreign investors, unless in 2015 country's total Gross Domestic Product fallen by $8 \%$ and side by side Turkish total Sukuk issuance decreased by $36.7 \%$, while in while in 2016 total Sukuk issuance increased by $85 \%$ to reach $\$ 5 \mathrm{~B}$ and slightly decreased in 2017 to reach $\$ 3.63 \mathrm{~B}$.

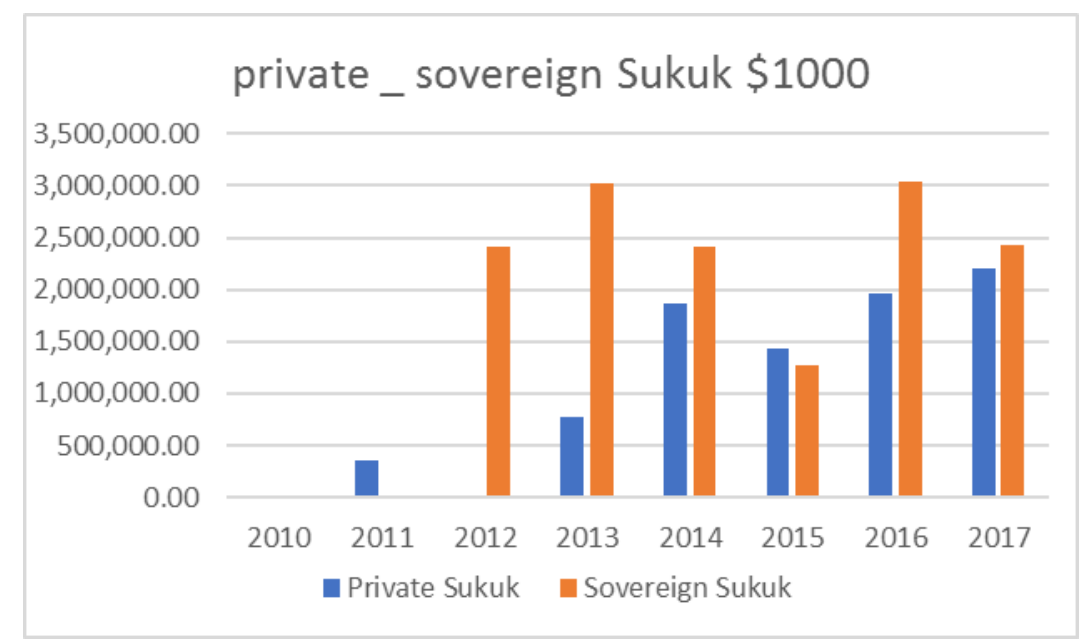

Figure 1: Turkish Lira Sukuk issuances have been converted US Dollar based on exchange rate issued on https://www.xe.com. Source: Turk Participation Banks union

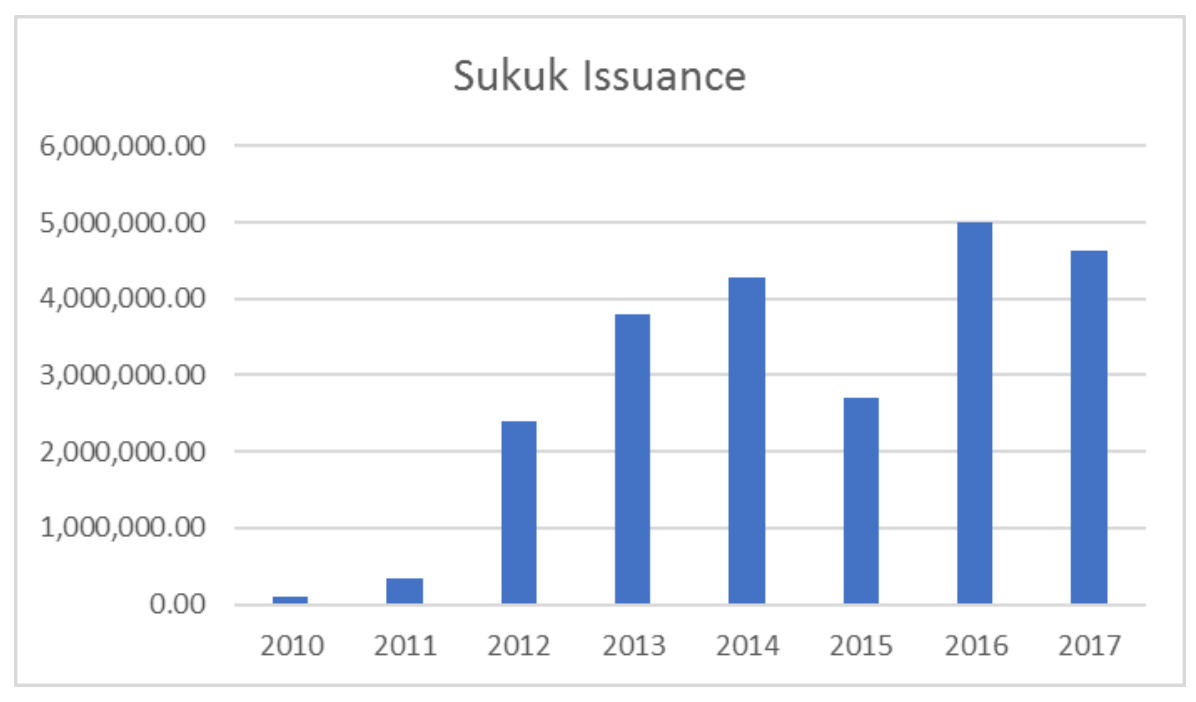

- Figure 2: Turkish Lira Sukuk issuances have been converted US Dollar based on exchange rate issued on https://www.xe.com. Source: Turk Participation Banks union 


\section{Sukuk Impact on Turkey GDP}

Turkish GDP growth rate during the period 2010-2017 is $1.55 \%$, chart 3 shows Turkish GPD through the period of study, in 2010 Turkish GDP was $\$ 772 \mathrm{~B}$ and grown by $7.85 \%$ to reach $\$ 832 \mathrm{~B}$ in 2011 , it kept increasing to reach $\$ 950.5 \mathrm{~B}$ in 2013 as it was the highest GDP in the Turkish history, then slightly dropped to reach $\$ 934$ B in 2014, in 2015, however, sharply dropped to \$859.8 and kept fluctuating slightly to reach \$851.1 B in 2017.

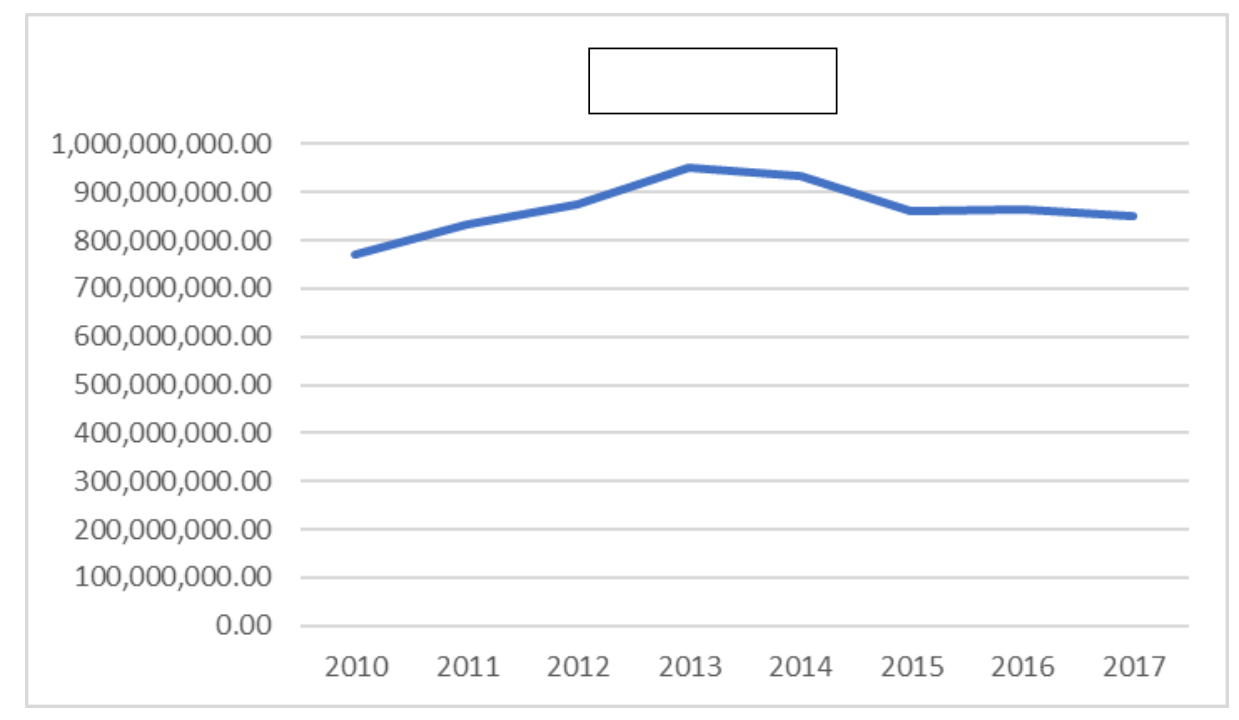

Figure 3: Source: World Bank Website

Table - 1: Sukuk impact on Turkish GDP 2010-2016

\begin{tabular}{|c|c|c|c|}
\hline Year & Sukuk Issuance & GDP & $\begin{array}{c}\text { Percentage of Sukuk Issuance } \\
\text { to GDP }\end{array}$ \\
\hline 2010 & $100,000.00$ & $771,902,000.00$ & $0.013 \%$ \\
\hline 2011 & $350,000.00$ & $832,524,000.00$ & $0.042 \%$ \\
\hline 2012 & $2,404,630.72$ & $873,982,000.00$ & $0.275 \%$ \\
\hline 2013 & $3,794,834.16$ & $950,579,000.00$ & $0.399 \%$ \\
\hline 2014 & $4,273,346.28$ & $934,186,000.00$ & $0.457 \%$ \\
\hline 2015 & $2,704,050.64$ & $859,797,000.00$ & $0.314 \%$ \\
\hline 2016 & $5,002,616.53$ & $863,722,000.00$ & $0.579 \%$ \\
\hline 2017 & $4,632,351.00$ & $851,100,000.00$ & $0.544 \%$ \\
\hline
\end{tabular}

From statistics we can understand that, Sukuk impact on Turkish GDP was increasing gradually except in 2015 as this year was associated with a decrease in GDP and a sharp drop in Sukuk issuance, and for the first time since sovereign Sukuk issuance has started in Turkey, sovereign Sukuk issuance was less than private ones which indicated a decrease in governmental performance in that year while in 2016 Sukuk issuance increased again to reach \$5 B and decreased slightly to \$4.6 B in 2017 this year also was associated with a decrease in sovereign Sukuk in increase in private Sukuk issuance.

The real beginning of Sukuk issuance in Turkey was in 2012 when the Turkish government started issuing sovereign Sukuk despite that there was no private Sukuk issuance in the same year. Sukuk issuance in 2012 was about \$2.4 B and impact on Turkish GDP was $0.275 \%$, this impact continued to increase to reach $0.457 \%$ in 2014 but it fell in $20150.399 \%$ as both government and private issued Sukuk less than the usual average. In 2016 total Sukuk issuance increased to reach \$5 B with an impact on Turkish GDP of $0.579 \%$ to record the highest rate since Sukuk issuance started in Turkey but this rate dropped slightly to reach $0.544 \%$ in 2017 . 
As the Turkish government prepared the required regulations to allow both public and private sector to issue Sukuk, Sukuk issuance witnessed a rapid growth especially sovereign Sukuk issuance, it can be mentioned that during the study period issued sovereign Sukuk represent $60 \%$ of Sukuk issued in Turkey. During the first two years of the study period, the impact of Sukuk on Turkish GDP cannot be considered due to the weak Sukuk issuance as the required regulations were under construction, while in the following years Sukuk impact on GDP was increasing gradually to reach $0.54 \%$ in 2017 . Sukuk issuance, however, is not dependent on the country's economic situation especially in 2015 when the Turkeys Republic suffered from a decrease of $8 \%$ in GDP.

\section{REFERENCES}

Afshar, Tahmoures A. (2013). Compare and Contrast Sukuk (Islamic Bonds) with Conventional Bonds, Are they Compatible. The Journal of Global Business Management Volume 9. Number 1.

ALPASLAN, Halil İbrahim \& Kudun, Candan. (2016). Sukuk Applications in Turkey and Its Tax Dimension. Journal of Life Sciences; Volume 6 Number 2/1. Batman University/Turkey.

Aslan, Hakan. (2012). Alternatif Bir Yatirim Ve Finansman Araci Olarak Sukuk: Yapisi, İşleyişi ve Türkiye Piyasasi İçin Öneriler. Master Theses. Sosyal Bilimler Enstitüsü. Marmara Üniversitesi/Turkey.

Buyukakin, Figen \& Onyilmaz, Onur. (2012) Faizsiz Finansman Bonosu Sukuk ve Türkiye Uygulamalaları̈ Finansal Araştırmalar ve Çalışmalar Dergisi. Cilt 3. Sayı 7.

Damak, M \& Volland, E 2008, The Sukuk Market Continues to Soar And Diversify, Held Aloft By Huge Financing Needs, Standard \& Poor's, New York.

Dusuki, Asyraf Wajdi. (2009). Challenges of Realizing Maqasid al-Shariah (Objectives of Shariah) in Islamic Capital Market: Special Focus on Equity-Based Sukuk paper presented at Keynote Address at the 3rd USM-ISDEV International Islamic Management Conference on Islamic Capital Market.

Ismail, Abdul Ghafar. (2010). Sukuk Structure: An International Comparison. Research Center for Islamic Economics and Finance. School of Economics. University of Kabangsaan. Malaysia.

Kusasi. et al. (2015). Sukuk as Alternative for Shipping Financing: International Standard and Malaysian Practice, pp. 98-106. The 1st International Conference on Maritime Development Proceeding. Tanjungpinang, September 4-6, 2015.

Lackmann. B., 2015. Types of Islamic Bonds (Sukuk) and History of Japanese Company Issuance. Nomura Journal of Capital Markets Winter 2015 Vol.6. No.3.

Laldin, Mohamad Akram. (2008) "Islamic financial system: the Malaysian experience and the way forward", Humanomics, Vol. 24 Issue: 3 , pp.217-238.

ÖZEROĞLU, A. İ. (2014). Sukuk and Assessment of Implementation Of Sukuk in Turkey. Tarih Okulu Dergisi(XIX), 751 -772

Safari, Meysam. (2013). Contractual and payoff patterns of Sukuk securities. The International Journal of Banking and Finance, Volume 10 (Issue 2): Page 81-110

Sarıkatipoğlu, Ata \& Çapkın, Timur Arif \& Özyiğit, Sinem "SUKUK IN TURKEY: LEGISTLATIVE HISTORY AND CURRENT PRACTICE/ Türkiye'de Sukuk: Tarihsel Gelişimi Ve Mevzuat Çerçevesinde Günümüz Uygulaması”, GSI ARTICLETTER 12 (2015 WINTER): 174-195.

Ulusoy, Ahmet \& Ela, Mehmet. (2015). Issuing Sukuk Certificates for sovereign Financing in Turkey: A General Overview. International Congress on Islamic Economics and Finance, P:143-169. 21-23 October 2015, Sakarya/Turkey.

ULUSOY, Ahmet \& Ela, Mehmet. (2016). SOVEREIGN SUKUK ISSUANCE AND ITS NECESSITY IN TURKEY. 2. International Congress of Social Sciences, China to Adriatic

Ulusoy, Ahmet \& Ela, Mehmet (2018). "EFFECT OF GLOBAL FINANCIAL CRISIS ON SUKUK MARKET" Osmaniye Korkut Ata University Journal of Economics and Administrative Sciences Vol:2, Issue:1, pp. 99-114

Usmani, M. T. (2007). Sukuk and their contemporary applications. Retrieved from

http://www.failaka.com/downloads/Usmani_SukukApplications.pdf 